\title{
Bacillus velezensis CC09: A Potential 'Vaccine' for Controlling Wheat Diseases
}

\author{
Xingxing Kang, Wanling Zhang, Xunchao Cai, Tong Zhu, Yarong Xue, ${ }^{\dagger}$ and Changhong Liu ${ }^{\dagger}$ \\ State Key Laboratory of Pharmaceutical Biotechnology, School of Life Sciences, Nanjing University, Nanjing, China
}

Accepted 23 January 2018.

\begin{abstract}
Biocontrol bacteria that can act like a "vaccine", stimulating plant resistance to pathogenic diseases, are still not fully elucidated. In this study, an endophytic bacterium, Bacillus velezensis CC09, labeled with green fluorescent protein, was tested for its colonization, migration, and expression of genes encoding iturin A synthetase within wheat tissues and organs as well as for protective effects against wheat take-all and spot blotch diseases. The results showed that strain CC09 not only formed biofilm on the root surface but was also widely distributed in almost every tissue, including the epidermis, cortex, and xylem vessels, and even migrated to stems and leaves, resulting in $66.67 \%$ diseasecontrol efficacy (DCE) of take-all and 21.64\% DCE of spot blotch. Moreover, the gene cluster encoding iturin A synthase under the control of the $p_{i t u}$ promoter is expressed in B. velezensis CC09 in wheat tissues, which indicates that iturin A might contribute to the in-vivo antifungal activity and leads to the disease control. All these data suggested that strain $\mathrm{CC09}$ can act like a 'vaccine' in the control of wheat diseases, with a single treatment inoculated on roots through multiple mechanisms.
\end{abstract}

Take-all is a soil-borne disease and spot blotch is a leaf disease of wheat, caused by Gaeumannomyces graminis var. tritici and Bipolaris sorokiniana, respectively, which lead to a severe yield loss annually (Bithell et al. 2016; McDonald et al. 2018). It has been reported that $G$. graminis var. tritici penetrates the wheat vascular system, expands to the stem base, and absorbs nutrients and water from the plants resulting in dwarf seedlings and death (Winter et al. 2014). Bipolaris sorokiniana infects wheat tissues in all growing stages and causes various symptoms, such as root rot, stem wilt, leaf wilt, white spike, and black embryo, and ultimately leads to a decrease in yield, due to the damage to leaf photosynthesis (Elwazziki et al. 2015). Besides, the black embryo of grain caused by Bipolaris sorokiniana also severely affects the quality and nutrition of wheat flour. Crop rotation, cultivation of disease-resistant varieties, and application of synthetic fungicides are the most commonly used procedures to control wheat spot blotch and take-all diseases (Acharya et al. 2010; Savary et al. 2017). In fact, it is not realistic to manage

${ }^{\dagger}$ Corresponding authors: Changhong Liu; E-mail: chliu@nju.edu.cn and Yarong Xue; E-mail: xueyr@nju.edu.cn

Funding: The research is financially supported by the Natural Science Foundation of China $(31471810,31272081,41773083)$ and the National Key R\&D Program of China (SQ2017YFNC060022-05).

*The $\boldsymbol{e}$-Xtra logo stands for "electronic extra" and indicates that one supplementary table is published online.

C 2018 The American Phytopathological Society these diseases in the modern agricultural system by either longterm rotation or cultivation of resistant varieties (which are not available yet), especially in China, with its large population and limited arable land. Although many synthetic fungicides, such as triazolone, carbendazim, and tebuconazole, have been used to control take-all and spot blotch diseases, long-term usage of these antifungal chemicals might have side effects on beneficial microorganisms, the ecological balance in the natural ecosystem, and even yield (Pereg and McMillan 2015).

In recent years, several studies have shown that many beneficial bacteria (e.g., Bacillus subtilis, Bacillus velezensis, Bacillus amyloliquefaciens, Pseudomonas fluorescens) could be used as effective and environmentally friendly biocontrol agents to protect wheat from take-all, spot blotch, and powdery mildew diseases (Alvarez et al. 2012; Liu et al. 2009; Shali et al. 2010; Yang et al. 2014; Zhang et al. 2006). Among these bacteria, B. velezensis possesses several obvious advantages, including specific colonization on certain parts of a given crop, formation of biofilms, production of antimicrobial metabolites, and induction of the systemic resistance of plants (Borriss et al. 2011; Cai et al. 2013; Choudhary and Johri 2009; Idriss et al. 2002). Genome analysis identified ten gene clusters involved in nonribosomal synthesis of bacillibactin, polyketides (macrolactin, bacillaene, and difficidin), lipopeptides (surfactin, fengycin, bacilysin, and iturin A), and bacteriocins (amylolysin and amylocyclicin) from B. velezensis LS69 (Liu et al. 2017). Among them, iturins and fengycins exhibit a broad antagonistic activity against phytopathogens and surfactins show strong antiviral, antimycoplasma, and antibacterial activities but no fungi (Cai et al. 2013; Kim et al. 2010). Moreover, iturin A has been reported to be the principal inhibitor in the biocontrol activity of $B$. velezensis and $B$. amyloliquefaciens against fungal pathogens (Arrebola et al. 2010; Gong et al. 2015; Liu et al. 2014). B. velezensis CC09, which was an endophytic bacterium isolated from healthy leaves of Cinnamomum camphora and previously identified as B. amyloliquefaciens $\mathrm{CC} 09$, shows great biocontrol efficacy in the control of many plant diseases, mainly due to the production of iturin A (Cai et al. 2013, 2016, 2017; Liu et al. 2014; Yang et al. 2014). In addition, like other Bacillus species, B. velezensis CC09 also produces endospores, which are strongly resistant to environmental stress and enhance vegetative cell survival in the field (Borriss et al. 2011). However, it was not clear whether the effective disease-control activity of $B$. velezensis on crops was caused by a direct action due to the production of an antifungal metabolite, iturin A, inside the plant tissues or an indirect function resulting from induced systemic resistance. Is it possible to control crop leaf diseases by inoculation of the biocontrol agent into roots? To address these questions, we applied B. velezensis CC09 labeled with green fluorescent protein (GFP), to test for its colonization, migration, and expression of genes encoding iturin A synthetase within wheat tissues and organs as well as for protective effects against wheat take-all and spot blotch diseases. 


\section{RESULTS}

Effects of plasmid PHT315-gfpmut $3 a$ on strain CC09.

Plasmid stability. The generation time of a Bacillus sp. was reported to be 50 to $100 \mathrm{~h}$ under natural conditions but 20 to 30 min per generation under laboratory conditions (Hecker and Völker 1990). In this study, we found that the plasmid PHT315gfpmut $3 a$ in strain CC09 (i.e., GFP-tagged CC09) was highly stable during culture at $37^{\circ} \mathrm{C}, 160 \mathrm{rpm}$ for $65 \mathrm{~h}$ (data not shown). Thus, GFP-tagged CC09 (Fig. 1) was used for subsequent studies,

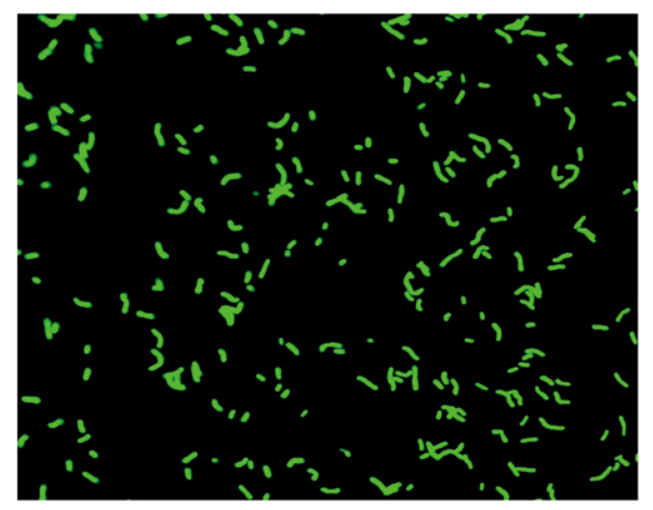

Fig. 1. The labeled endophytic bacterial strain CC09 observed by confocal laser scanning microscopy. including the examination of colonization and migration ability using confocal laser scanning microscopy (CLSM).

Growth curves of GFP-tagged CC09. Measurement of growth showed that GFP-tagged CC09 and WT-CC09 (wild-type strain CC09) exhibited the same growth curve pattern (Fig. 2), which indicated that the plasmid PHT315-gfpmut $3 a$ did not have any impact on the growth behavior of the bacterium. Thus, GFPtagged CC09 instead of WT-CC09 was used to track the distribution of strain $\mathrm{CC} 09$ in plants postinoculation.

Antagonistic activity. According to the size of the inhibited zone of G. graminis var. tritici and Bipolaris sorokiniana on potato dextrose agar (PDA) medium, the effect of GFP-tagged CC09 was not significantly different from the effect of WT-CC09 (Fig. 3), which indicated that the existence of plasmid PHT315-gfpmut $3 a$ in the bacterial cells did not alter the antifungal activities of the bacterium. Due to the persistent existence of the plasmid in cells and the unchanged growth and antagonistic activity, the GFPtagged CC09 was used in the following experiments instead of WT-CC09.

\section{Dynamics of GFP-tagged CC09 in wheat plants.}

Based on CLSM observations, we found that GFP-tagged CC09 could efficiently colonize wheat roots and, then, move from the roots to the stems and leaves (Fig. 4). One day after inoculation, the GFP-tagged CC09 formed a dense biofilm on the adventitious (Fig. 4A) and lateral roots (Fig. 4B), and only a few cells invaded root tissues (Fig. 4C). At 4 to 7 days after inoculation, large numbers of bacterial cells were observed on

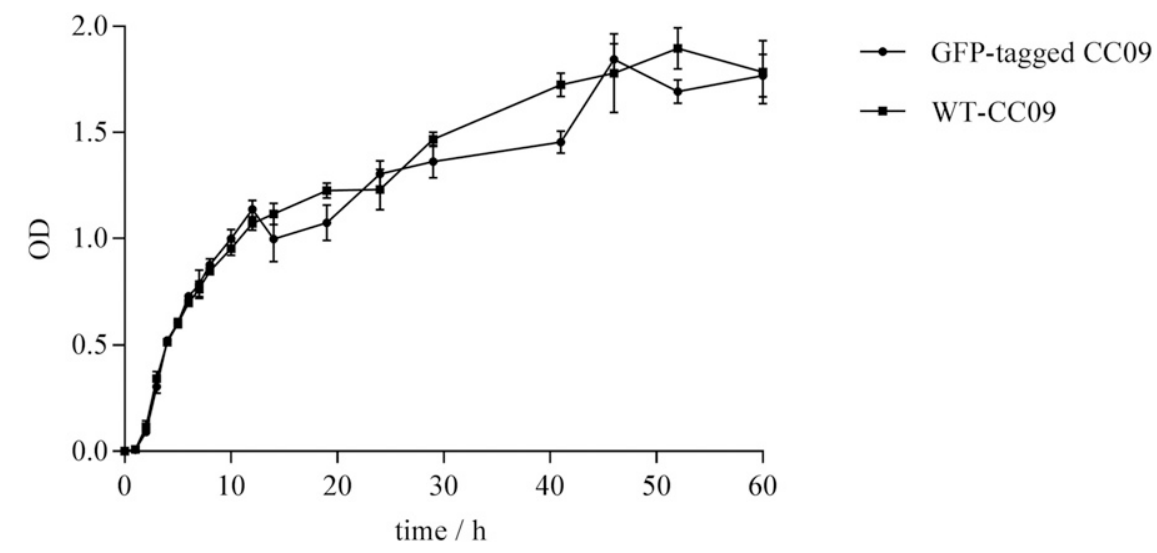

Fig. 2. Comparison of the growth of Bacillus velezensis CC09 and green fluorescent protein (GFP)-tagged CC09. Growth in Luria Bertani was estimated by continuous measurements of optical density at $600 \mathrm{~nm}$ for $60 \mathrm{~h}$. The datapoints represent the means and the bars represent the standard errors of the means of the results from three replicate treatments.
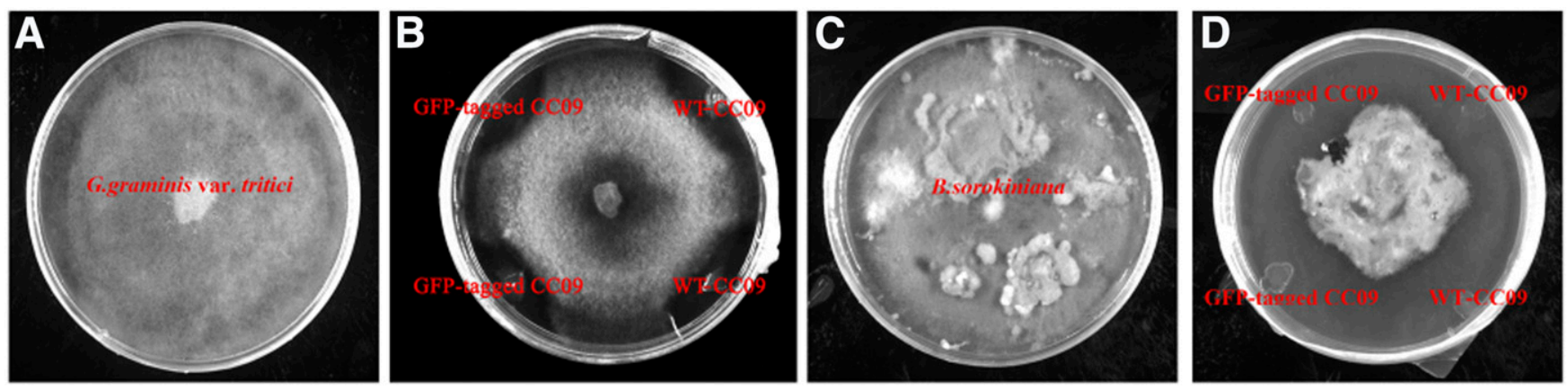

Fig. 3. Antagonism against Gaeumannomyces graminis var. tritici and Bipolaris sorokiniana of Bacillus velezensis CC09 and green fluorescent protein-tagged CC09. A, Growth of G. graminis var. tritici on potato dextrose agar (PDA) for 12 days without bacteria. B, Cultures at the same age showing the inhibition of G. graminis var. tritici growth by the CC09 strain. C, Growth of Bipolaris sorokiniana on PDA for 17 days without bacteria. D, Cultures at the same age showing the inhibition of Bipolaris sorokiniana growth by the CC09 strain. 


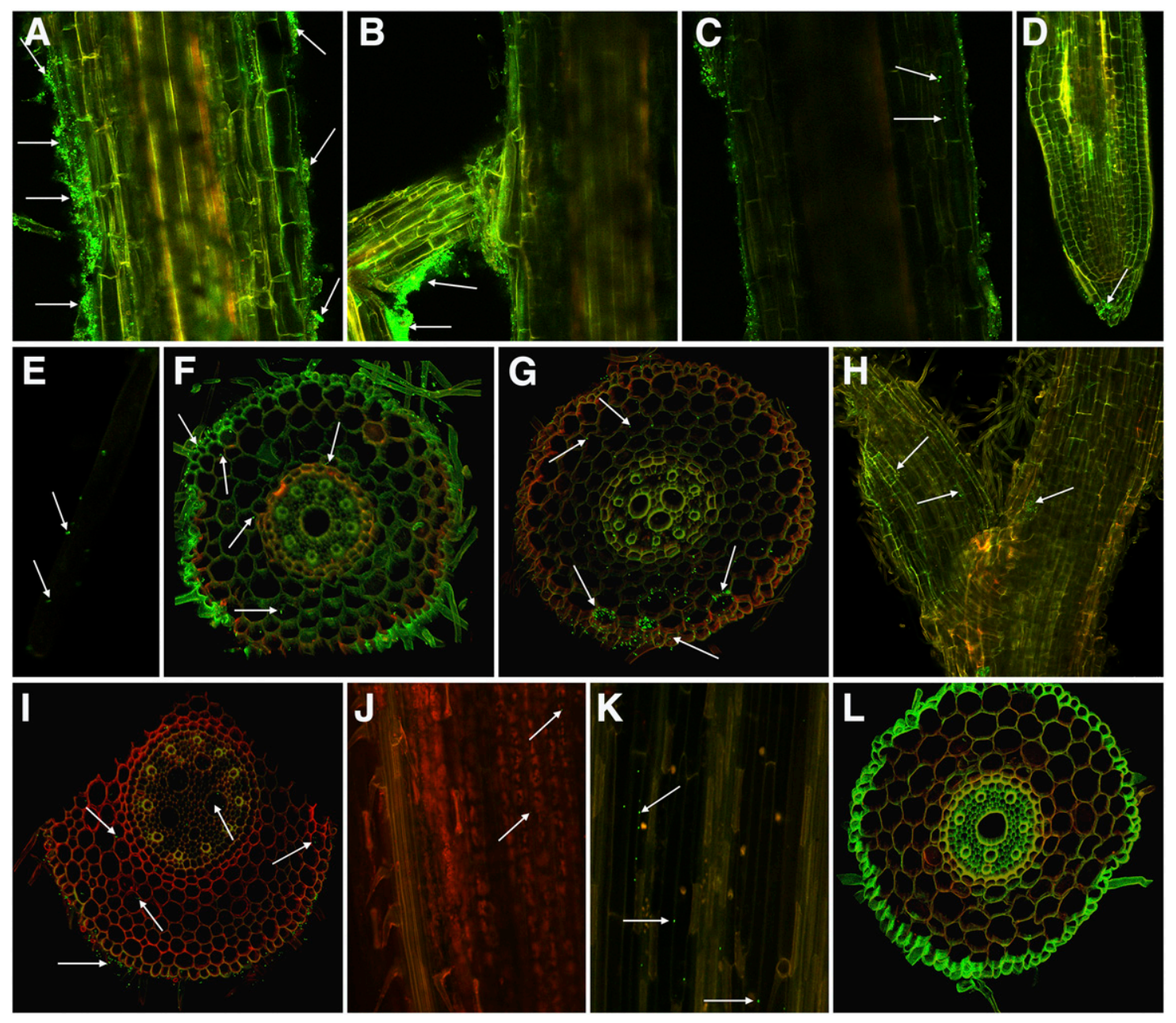

Fig. 4. Confocal laser scanning microscopy images of the colonization of wheat seedling roots by CC09-tagged with green fluorescent protein-expressing plasmids. The bacterial cells formed dense biofilm on $\mathbf{A}$, the surfaces of the adventitious roots, $\mathbf{B}$, the zone of lateral roots, and $\mathbf{C}$, the vertical section 1 day after inoculation. D, Transverse sections or vertical sections of adventitious roots showed the increasing bacteria distributed on the root tips and $\mathbf{E}$, some located within root hair cells, and $\mathbf{F}$, epidermis and cortical layers at 4 days after inoculation. G, Bacteria progressed toward the inner cortex and $\mathbf{H}$, the lateral junction at 7 days after inoculation. I, Bacteria had colonized the pith and xylem vessels of the primary root 10 days after inoculation. J, The bacteria were found in leaf tissue and $\mathbf{K}$, stem tissue at 15 days after inoculation. $\mathbf{L}$, Wild type strain CC09 inoculation. The arrows indicate the expression of $g f p m u t 3 a$ in the inoculated CC09 cells.

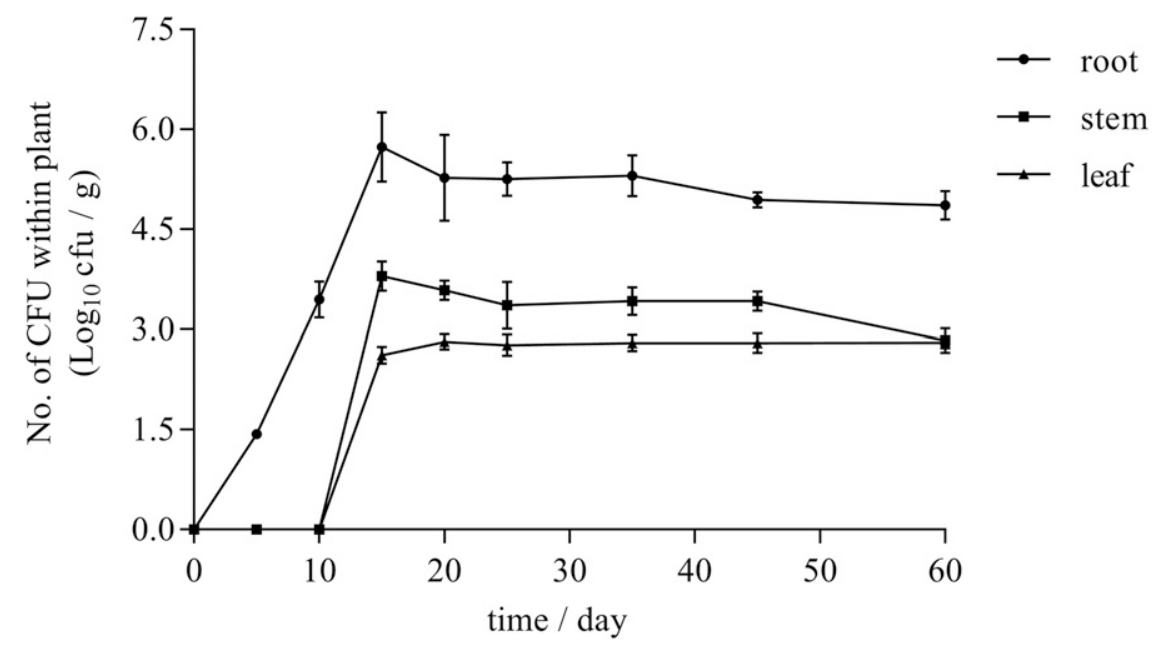

Fig. 5. Number of bacterial colony forming units (CFU) recovered from the interiors of roots, stems, and leaves with a $1 \times 10^{8} \mathrm{CFU} / \mathrm{ml}$ inoculum level. The datapoints represent the means, and the error bars indicate standard deviation of the means calculated from three independent samples. 
root tips (Fig. 4D), hairs (Fig. 4E), epidermis, and cortical layers (Fig. 4F and G). In particular, the cell number at the intersection between the lateral and adventitious roots was significantly increased compared with the cell number in the adventitious roots (Fig. 4H). By day 10, the cells of GFP-tagged CC09 were found in almost all the root tissues, such as epidermis, cortex, pith, and xylem vessels (Fig. 4I). However, a few cells were observed in the tissues of the leaves (Fig. 4J) and stem (Fig. 4K) at day 15 postinoculation. These data were indicative that the biocontrol agent $B$. velezensis $\mathrm{CC} 09$ not only effectively colonizes wheat plants but also vertically moves from roots to leaves through the stems. This property gives strain $\mathrm{CC} 09$ the potential to protect both wheat roots and leaves from fungal diseases by a single application of the strain on the roots.

To understand the dynamic changes of the cell population within wheat roots, stems, and leaves, the number of the GFPtagged CC09 cells was counted, using the dilution-plating method. Results showed that the cell number in wheat roots, stems, and leaves rapidly increased during the first 15 days, decreased from 15 days to 20 days, and reached a stable level afterward, in a light chamber at $25^{\circ} \mathrm{C}$, with a light period of $14 \mathrm{~h}$ per day (Fig. 5).

\section{Effect of GFP-tagged CC09 concentrations on wheat growth.}

The GFP-tagged CC09 showed a great effect on wheat growth, such as on root number and biomass. Basically, the adventitious root size was enhanced by the strain at inoculation concentrations of $1 \times 10^{6}$ and $1 \times 10^{7} \mathrm{CFU} / \mathrm{ml}$; however, they were inhibited by the strain at $1 \times 10^{8} \mathrm{CFU} / \mathrm{ml}$. Moreover, the GFP-tagged CC09 significantly improved the size and density of lateral roots at initial inoculation concentrations of $1 \times 10^{7}$ $\mathrm{CFU} / \mathrm{ml}$ and $1 \times 10^{8} \mathrm{CFU} / \mathrm{ml}$, respectively. In addition, the GFP-tagged CC09 did not show any significant effect on the size and biomass of wheat parts that were above the ground as well as the adventitious root mass at the given inoculation concentrations (Fig. 6).

Table 1. Biocontrol effect of after sowing with the endophytic Bacillus velezensis $\mathrm{CC} 09$ on take-all disease and spot blotch diseases of wheat in the greenhouse

\begin{tabular}{lllc}
\hline Diseases & \multicolumn{1}{c}{ Treatments } & DI \pm SD $^{\mathbf{a}}$ & DCE $^{\mathbf{b}}(\boldsymbol{\%})$ \\
\hline Take-all & Sterile water & 0 & 0 \\
& Strain CC09 (Bv) & 0 & 0 \\
& Gaeumannomyces graminis & $84.47 \pm 3.87 \mathrm{a}$ & 100 \\
& $\quad$ var. tritici treatment (Ggt) & & \\
& Biocontrol treatment (Bv-Ggt) & $28.16 \pm 1.77 \mathrm{~b}$ & 66.67 \\
Spot blotch & Sterile water & 0 & 0 \\
& Strain CC09 (Bv) & 0 & 0 \\
& Pathogenic fungus (Bs) & $88.33 \pm 2.89 \mathrm{a}$ & 100 \\
& Fungicide-fungus (Tri-Bs) & $51.81 \pm 2.56 \mathrm{c}$ & 41.34 \\
& Bacterium (R)-fungus (Bv(r)-Bs) & $69.22 \pm 3.72 \mathrm{~b}$ & 21.64 \\
& Bacterium (L)-fungus (Bv(l)-Bs) & $33.95 \pm 2.00 \mathrm{~d}$ & 61.56 \\
\hline
\end{tabular}

${ }^{a}$ Disease index (DI) \pm standard deviation (SD). Letters from a to d indicate that the DIs among different treatments of take-all ( $a$ and $b$ ) and spot blotch (a, b, c, and d) and control experiments were significantly different $(P<0.05)$ by Fisher's least significant difference test.

$\mathrm{b}$ DCE $=$ disease-control efficacy.
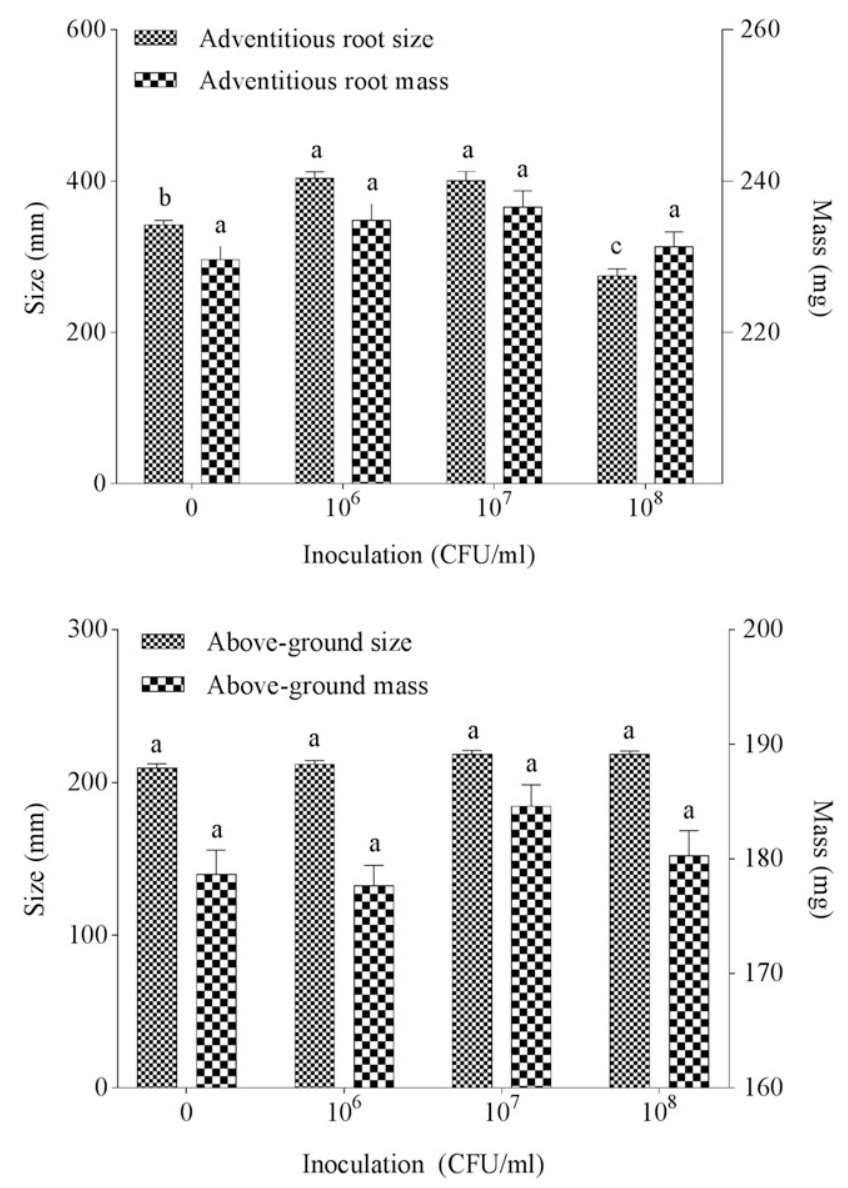

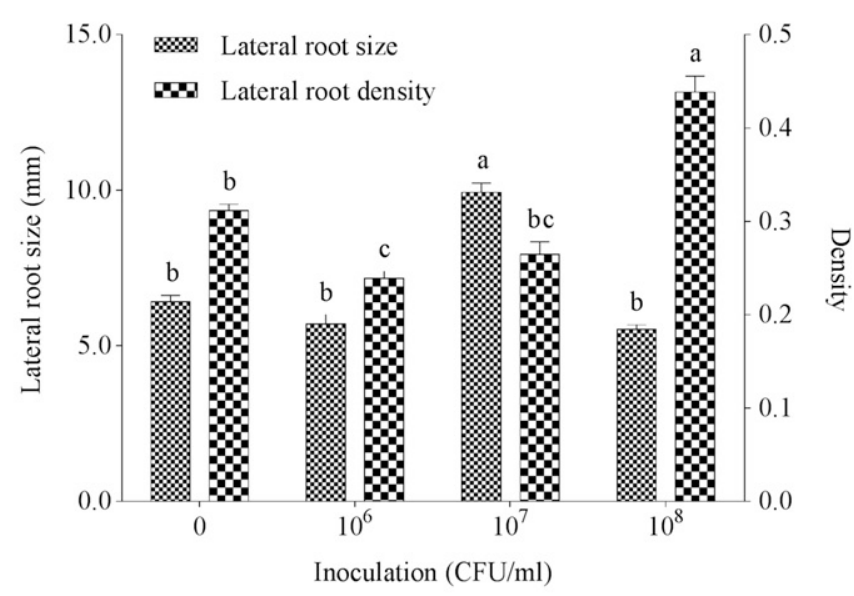

Fig. 6. Effect of Bacillus velezensis $\mathrm{CC} 09$ on the growth of root and above-ground parts with different inoculum levels. The datapoints represent means \pm standard deviation of three replicate experiments. The differences in letters indicate a significant difference between treated and control samples based on Fisher's least significant difference test at $P=0.05$. 


\section{Biocontrol efficiency of GFP-tagged CC09} against wheat take-all and spot blotch diseases.

To test whether the GFP-tagged CC09 could efficiently protect wheat roots and leaves from pathogenic fungal infection, we conducted two independent experiments under fully controlled conditions targeting both take-all and spot blotch diseases. Results showed that the disease incidence (DI) of take-all disease was significantly reduced to $28.16 \%$ with a disease-control efficacy (DCE) of $66.67 \%$, compared with a DI of $84.47 \%$ and a DCE of $100 \%$ in the G. graminis var. tritici treatment (Ggt) group after 20 days. No diseased plants were observed in either the control group $(\mathrm{CK})$ or the strain $\mathrm{CC} 09$ treatment $(\mathrm{Bv})$ group (Table 1).

In another independent controlled experiment, the DI of spot blotch was dramatically decreased to $33.95 \%$ with a DCE of $61.56 \%$ by spraying GFP-tagged CC09 on leaves (disease protected by leaf inoculation of GFP-tagged $\mathrm{CC} 09$ [Bv(l)-Bs]) and to $69.22 \%$ with a DCE of $21.64 \%$ by inoculating the strain on roots (disease protected by root inoculation of GFP-tagged CC09 [Bv(r)$\mathrm{Bs}]$ ). Obviously, the DIs of wheat spot blotch in $\mathrm{Bv}(\mathrm{l})-\mathrm{Bs}$ and $\mathrm{Bv}$ (r)-Bs treatments were significantly lower than in the Bipolaris sorokiniana control (Bs) $(88.33 \%)$ (Table 1). The lower DCE in $\mathrm{Bv}(\mathrm{r})$ - $\mathrm{Bs}$ than in $\mathrm{Bv}(\mathrm{l})$ - $\mathrm{Bs}$ is suggestive that the bacterium might take time to move from roots to leaves and effect its antifungal role.

\section{Mechanism of strain CC09 control of wheat root and leaf diseases.}

Wheat biomass. By measuring plant growth, it was found that root size in the Bv group was significantly decreased in comparison with the CK but was significantly increased compared with the Ggt and biocontrol treatment (Bv-Ggt) groups. However, root mass in the $\mathrm{Bv}$ group remained almost the same as the $\mathrm{CK}$, whereas root mass in Ggt and Bv-Ggt groups was dramatically decreased (Fig. 7). This result was consistent with the previous experiment in which GFP-tagged CC09 caused significant inhibition at $1 \times 10^{8} \mathrm{CFU} / \mathrm{ml}$. The reason for the lack of a significant difference between Ggt and $\mathrm{Bv}-\mathrm{Ggt}$ groups was probably due to the severe impact of $G$. graminis var. tritici infection on root growth, but biocontrol treatment still weakens root inhibition by $G$. graminis var. tritici infection to some extent, in spite of no obvious function. Above-ground parts of wheat were not affected by the GFP-tagged CC09 inoculation. However, relative to its effect in the $\mathrm{CK}$ and $\mathrm{Bv}$ group, G. graminis var. tritici infection showed dramatically imposed restrictions on the above-ground size of wheat but had no effect on above-ground mass.

Inhibition of fungal growth and spread within root tissues. With the assistance of light microscopy, the morphology of G. graminis var. tritici and Bipolaris sorokiniana was observed in untreated samples (Fig. 8A and B) and after inoculation with the GFP-tagged CC09 during the antagonistic activity test. Results clearly demonstrated that the mycelial surface became rough, the hyphal tip was swollen (Fig. 8C and D), and cell contents were released due to the lytic effect of the GFP-tagged CC09 on mycelium. Moreover, GFP-tagged CC09 also significantly inhibited mycelial density and the spread of $G$. graminis var. tritici in wheat roots. For instance, at 5 days postinoculation in the take-all disease-control experiment, a massive mycelium of $G$. graminis var. tritici was found in the cortex and some mycelium was even found in the stele of root tissues (Fig. 8E) in the Ggt group; however, only a few mycelia were observed in the root cortex in the Bv-Ggt group (Fig. 8F). Both the in-vitro and in-vivo data are strongly suggestive that the GFP-tagged CC09 directly inhibits or damages fungal cells, or both, leading to the high DCE.

Promoting activities of defensive enzymes. Based on the two independent controlled disease experiments mentioned above, three defensive enzymes, phenylalanine ammonialyase (PAL), polyphenol oxidase (PPO) and peroxidase (POD), were measured in roots (Fig. 9A) and leaves (Fig. 9B). In the wheat takeall control experiment compared with the $\mathrm{CK}$, the activities of PAL and PPO were significantly increased by inoculation of strain $\mathrm{CC} 09$ and were further enhanced by G. graminis var. tritici infection in the Ggt and Bv-Ggt groups. However, no difference was observed for POD activity among the four given treatments (Fig. 9A).

In the spot blotch control experiment, we found the activities of the three defensive enzymes (PAL, PPO, and POD) in wheat leaves were enhanced by inoculation with the GFP-tagged $\mathrm{CC} 09$ ( $\mathrm{Bv}$ group) and in the $\mathrm{Bs}, \mathrm{Bv}(\mathrm{r})-\mathrm{Bs}$, and $\mathrm{Bv}(\mathrm{l})$ - $\mathrm{Bs}$ groups compared with the activities in the blank control. Interestingly, the activities of these enzymes in leaves were significantly increased by inoculation of the strain onto the roots. Moreover, the activities in $\mathrm{Bv}(\mathrm{r})-\mathrm{Bs}$ and $\mathrm{Bv}(\mathrm{l})$ - $\mathrm{Bs}$ groups did not show any significant difference but were higher than those in the $\mathrm{Bv}$ and Bs groups, suggesting the existence of a synergistic effect on the enzyme's activity between the given bacterium and fungus.

Expression of gene clusters encoding antifungal metabolite iturin A. With the assistance of plasmid pH-IT-GFP_CC09, which contains promoter $\mathrm{p}_{\text {itu }}$ of the gene cluster encoding iturin A synthetase fused with the reporter gene encoding GFP, we tried to understand whether B. velezensis could produce antifungal metabolite iturin A inside plant tissues at the transcriptional level. The results of the CLSM observation showed that the bacterial cells were widely distributed both on the root
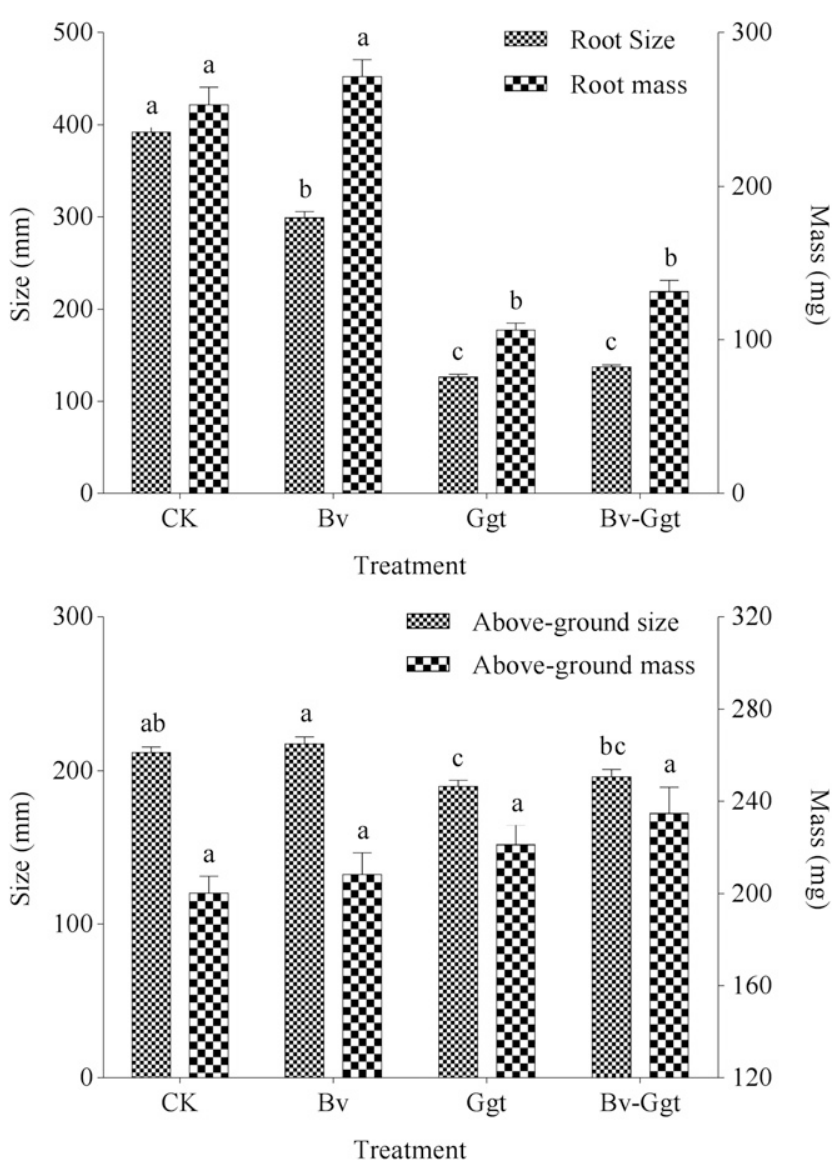

Fig. 7. Effect of endophytic bacterium Bacillus velezensis $\mathrm{CC} 09$ at inoculum levels of $1 \times 10^{8} \mathrm{CFU} / \mathrm{ml}$ and Gaeumannomyces graminis var. tritici infection on the growth of root and above-ground parts of the plant. Bars plot the means \pm standard deviation of three replicate experiments. The differences in letters indicate a significant difference between treated and control samples based on Fisher's least significant difference test at $P=0.05$. 
surface and in tissues such as the epidermis, cortex, and xylem vessels at 10 days postinoculation (Fig. 10A and B). In addition, real-time reverse transcription-polymerase chain reaction (RT-PCR) analysis demonstrated that the genes (i.e., ituA, ituB, $i t u C$, and ituD) encoding iturin A synthetase were expressed not only in roots but also in leaves. The expression levels of these genes within root or leaf tissues were not significantly different, but they were much higher in roots than in leaves $(P<0.05)$ (Table 2). Although we did not detect iturin A concentration in plants, the result of transcriptional expression of itu genes within root and leaf tissues strongly indicated that $B$. velezensis might be able to produce the metabolite in vivo, contributing to the effective control of take-all and spot blotch diseases.

\section{DISCUSSION}

Colonization ability is an important indicator of a bacterium with biocontrol potential. Like other biocontrol species of genus Bacillus, B. velezensis CC09 could not only form biofilm on root surfaces (Cai et al. 2016, 2017) but could also colonize root tissues, including the cortex, xylem vessels, and pith, as an endophytic bacterium. The genome sequence of $B$. velezensis CC09 revealed that this strain contains a large number of functional genes related to bacterial motility and chemotaxis (Cai et al. 2016), which played important roles in biofilm formation (Merritt et al. 2007; Zhang et al. 2014). It has been reported that efficient biofilm-forming beneficial bacteria could be used as potential biocontrol agents to control plant diseases under field conditions, due to enhanced root colonization and strong survival under stress condition (Haggag and Timmusk 2008). Thus, the genetic traits in B. velezensis CC09 might enable the strain to be a good biocontrol agent.
B. velezensis $\mathrm{CC} 09$ is an endophytic bacterium that was isolated from Cinnamomum camphora leaf tissue. In this study, we initially confirmed that this strain not only colonized successfully in wheat root tissues including the epidermis, cortex, and stele but, also, migrated upwards from roots to leaves through the stems. A similar phenomenon was reported by James et al. (2000), who found that endogenous nitrogen-fixing bacteria could invade the cortex and stele of Saccharum spp., Oryza sativa, and Leptochloa fusca, from where the bacteria could migrate into the aerial part of the plant. The migration of endophytic bacteria from roots to the stem and leaves might be achieved by transport via the xylem vessels and pith (James et al. 2000).

The effect of B. velezensis $\mathrm{CC} 09$ on wheat root growth was quite complicated, dependent on both concentrations of strain CC09 cells and root types. At lower concentrations $\left(1 \times 10^{6}\right.$ to $1 \times$ $10^{7} \mathrm{CFU} / \mathrm{ml}$ ), the GFP-tagged CC09 promotes the growth of adventitious roots; however, it inhibits the growth of adventitious roots but improves the development of lateral roots at high concentrations. Although the mechanism of the correlation between cell concentrations and root growth remains unclear, it might be associated with the production of phytohormones, such as auxins produced by $B$. velezensis. In fact, the production of phytohormones such as IAA (indole-3-acetic acid) by plant growthpromoting rhizobacteria (PGPR) has been proposed as one of the major mechanisms responsible for the observed plant-growth effects in which a low amount of IAA can stimulate primary root elongation, whereas high IAA levels decrease primary root length, increase root hair formation, and stimulate the formation of lateral roots (Mangmang et al. 2015; Spaepen et al. 2014; Vacheron et al. 2013). This plant growth-promoting effect mediated by IAA has been proved in many plant-PGPR systems, using either DR5::GUS transgenic reporter lines (Contesto et al. 2010;

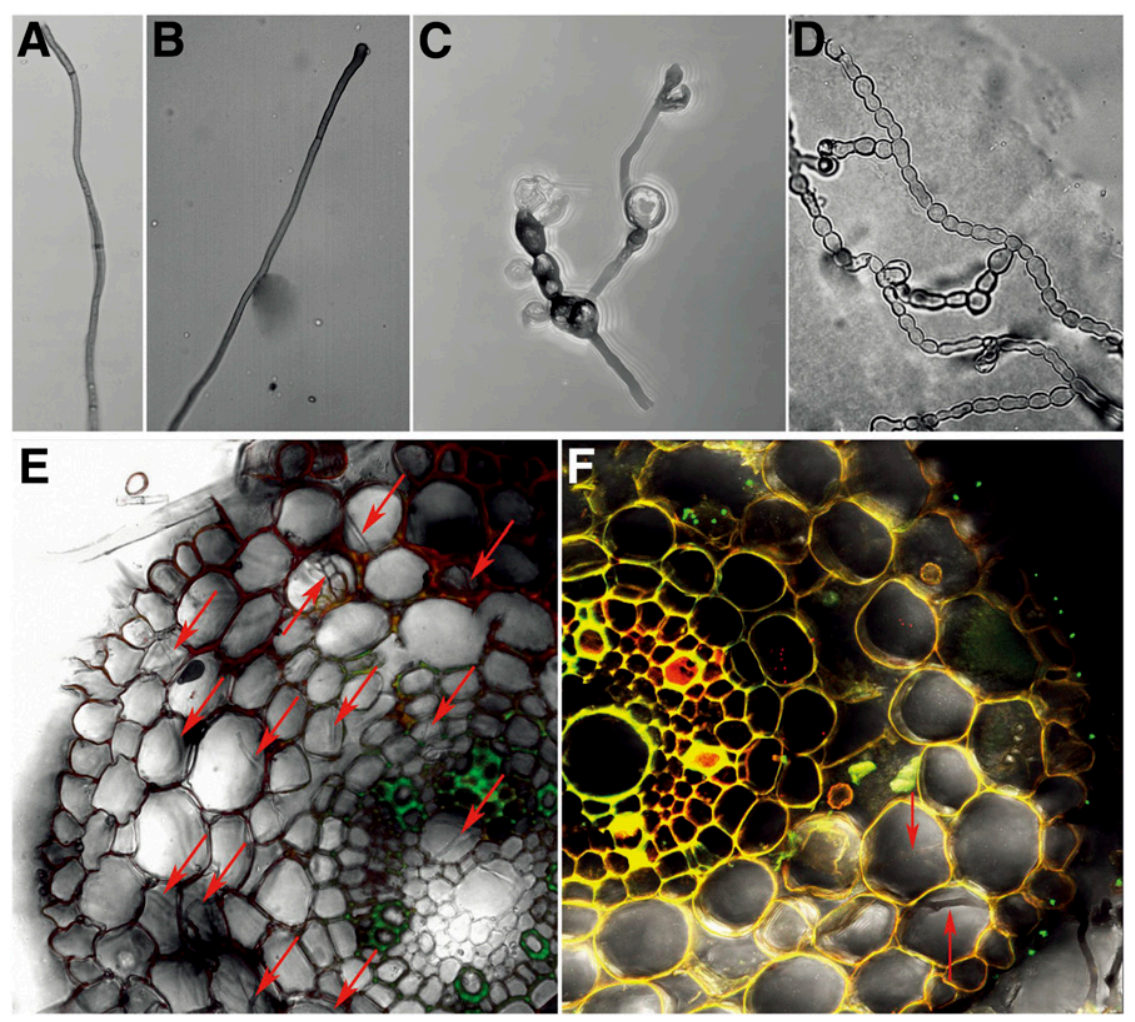

Fig. 8. Light microscopy showing the effects of B. velezensis $\mathrm{CC} 09$ on the morphology of the hyphae of Gaeumannomyces graminis var. tritici and Bipolaris sorokiniana. A, Hyphae of untreated G. graminis var. tritici. B, Hyphae of untreated Bipolaris sorokiniana. C, Hyphae of G. graminis var. tritici were swollen and shriveled. D, Hyphae of Bipolaris sorokiniana treated with the endophytic B. velezensis CC09 were swollen and shriveled. E and F, Confocal laser scanning microscopy micrographs of the colonization of the roots of wheat seedlings by G. graminis var. tritici in the absence (E) and presence (F) of the endophytic B. velezensis $\mathrm{CC} 09$, at 5 days. Arrows indicate the hyphae of $G$. graminis var. tritici. 
Spaepen et al. 2014) or higher IAA concentrations applied to the seeds by enhancing the inoculum density on roots (Mangmang et al. 2015). For example, Azospirillum brasilense is a well-known PGPR that can have a positive impact on plant growth when present in sufficient density. The endogenous IAA concentrations increased up to 55 and $>300 \%$ in cucumber and
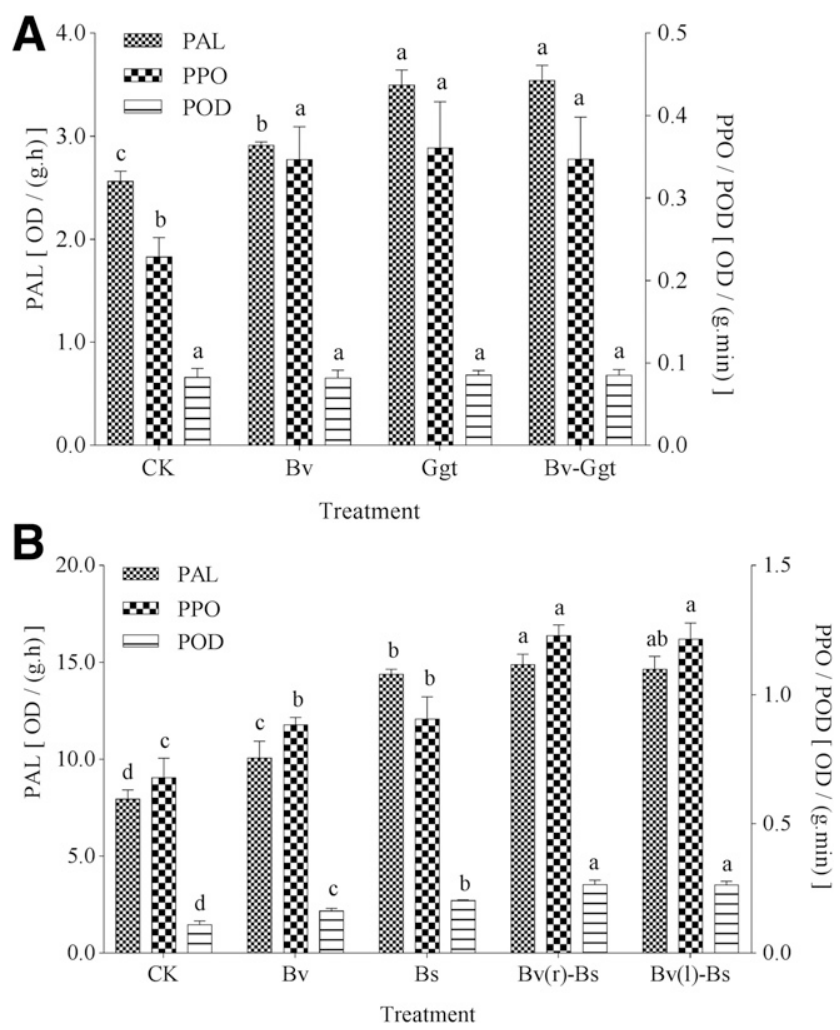

Fig. 9. Effect of CC09 strain inoculation on the induction of total peroxidase (POD), polyphenol oxidase (PPO), and phenylalanine ammonialyase (PAL). A, The defense activity for roots. $\mathbf{B}$, The defense activity for leaves. Bars plot the means \pm standard deviation of three replicate experiments. The differences in letters indicate a significant difference between treated and control samples based on Fisher's least significant difference test at $P=$ 0.05 tomato, respectively, by inoculation with $A$. brasilense $\mathrm{Sp} 245$ at $1 \times 10^{8} \mathrm{CFU} / \mathrm{ml}$, leading to dramatic effects on root biomass (Mangmang et al. 2015). Thus, the positive as well as negative effects of $B$. velezensis $\mathrm{CC} 09$ on wheat growth might be mainly dependent on the production and concentration of exogenous or endogenous auxins (e.g., IAA) controlled by the strain.

Production of a variety of antibiotics, such as lipopeptides and polyketones, might be the main mechanism by which $B$. velezensis CC09 protects wheat from fungal diseases (Cai et al. 2013; Chen et al. 2007; Chowdhury et al. 2015). These compounds were also reported to cause morphological changes of the pathogens (Pandya and Saraf 2014). In this study, we have demonstrated that iturin A-producing strain CC09 leads to abnormal mycelia of $G$. graminis var. tritici and Bipolaris sorokiniana. In fact, about $8.2 \%$ of the genes in the genome of B. velezensis CC09 are associated with the metabolism of lipopeptides and polyketones (Cai et al. 2016). Thus, the antibiotics such as iturin A produced by B. velezensis CC09 might play key roles in the growth and reproduction inhibition of phytopathogens such as G. graminis var. tritici and Bipolaris sorokiniana.

Although many researchers have proved that iturin A is one of the bioactive compounds contributing to disease-control effects (Cai et al. 2013; Crane et al. 2013; Gong et al. 2015), it was unclear whether the given bacterium, indeed, produced iturin A inside plant tissues in which it exerted its antimicrobial activities. Fernando et al. (2016) tried to investigate the production of lipopeptides in the roots, stems, and leaves of soybean that was inoculated by B. amyloliquefaciens 629 using ultra performance liquid chromatography (UPLC). Unfortunately, they did not detect the presence of lipopeptides, including surfactants, fengycins, and iturins, in the soybean plants and suggested that this result might be due to the sensitivity of UPLC. In this study, we used molecular methods to try to understand whether the gene cluster encoding iturin A synthases could be expressed in vegetative cells of $B$. velezensis CC09 inside wheat tissues. Our results demonstrated that both the reporter gene (gfpmut $3 a$ ) and the itu genes (ituA, ituB, ituC, and $i t u D$ ) were, indeed, expressed in $B$. velezensis that inhabited the plant tissues of wheat under the control of the $p_{\text {itu }}$ promoter (Fig. 10; Table 2). Although we do not know whether the transcripts of the iturin A synthase-encoding genes could be translated in the cells, exported out of the cells, or directly played antifungal roles in plant tissues in vivo, it at least proves that, at the transcriptional
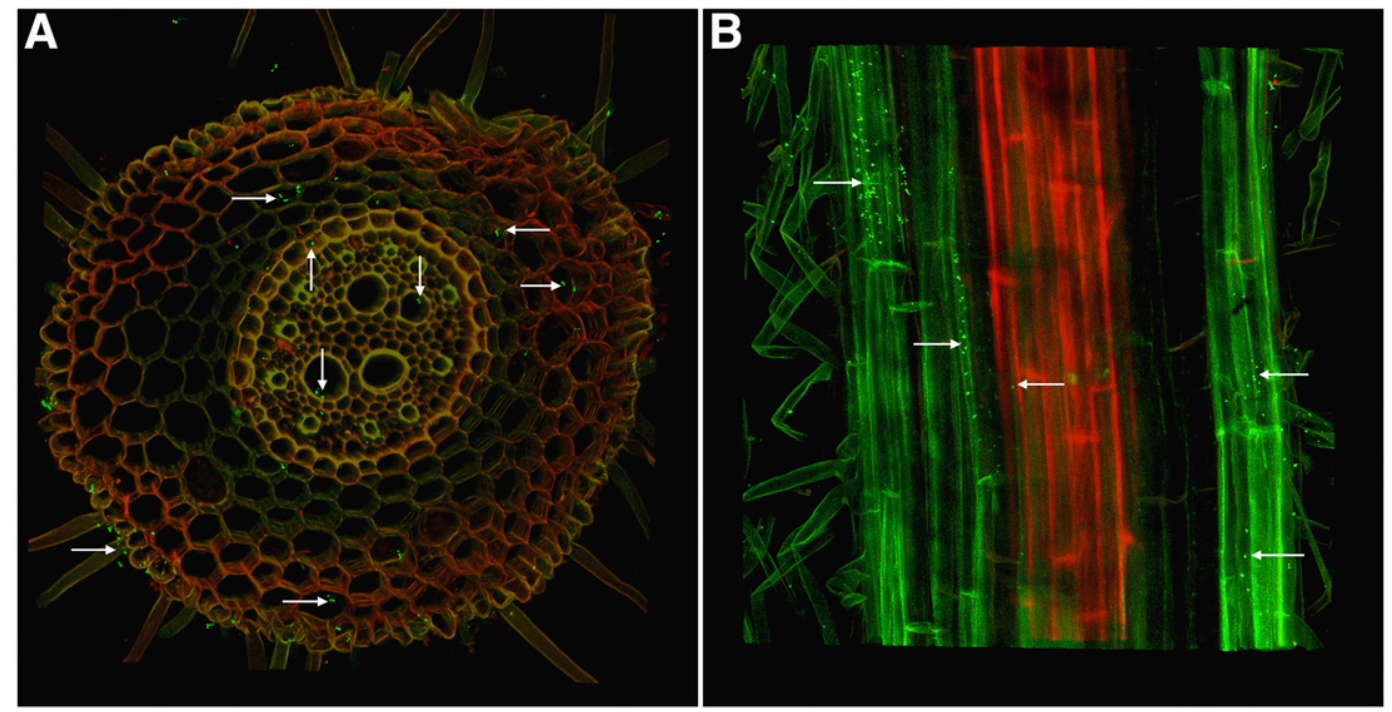

Fig. 10. Confocal laser scanning microscopy images of the colonization of wheat seedling roots by CC09 tagged with green fluorescent protein-expressing plasmids. A, A transverse section and $\mathbf{B}$, a vertical section of the adventitious roots showing the bacteria distributed in the epidermis, cortex, pith, and xylem vessels at 10 days after inoculation. The arrows indicate the expression of gfpmut $3 a$ in the inoculated CC09 cells. 
level, genes encoding lipopeptides are fully expressed in the bacterial cells. The practical role of iturin A produced by B. velezensis CC09 in plants against fungal infection is worthy of further study in the future.

Several mechanisms, such as the production of antimicrobial compounds and the induction of systemic resistance, have been reported for the protection of crops from diseases by biocontrol bacteria (Gong et al. 2015; Verbon and Liberman 2016). Our study demonstrated that the biocontrol properties of B. velezensis $\mathrm{CC} 09$ against take-all and spot blotch diseases were associated with these mechanisms. The bacteria not only expressed genes encoding antifungal metabolite iturin A synthase within cells but also induced long-distance disease resistance. For instance, wheat roots treated by B. velezensis CC09 once showed a $21.64 \%$ DCE of spot blotch (leaf disease). This remote DCE by strain CC09 was possibly due to induced systemic disease resistance and enhancement of the defensive enzymatic activities. In fact, genomic analysis of $B$. velezensis $\mathrm{CC} 09$ revealed that this strain contains many genes encoding plant-induced resistance factors, such as $y s n E$, dhaS, $y h c X$, and others (Cai et al. 2016). In addition, the migration ability of $B$. velezensis $\mathrm{CC} 09$ from roots to stems and leaves might be another important mechanism related to the remote DCE of wheat, since the genes encoding the antifungal metabolite iturin A synthetase in bacterial cells could be expressed in situ within leaf tissues when the bacteria moved from the inoculated roots to the leaves. Compared with the high DCE $(61.56 \%)$ of root-inoculation treatments, the lower DCE against spot blotch $(21.64 \%)$ of strain CC09 under the leaf-spraying treatment indeed revealed the presence of a remote disease-control mechanism in B. velezensis CC09. In other words, strain CC09 acted like a 'vaccine', protecting wheat from both root and leaf diseases once it was inoculated on the roots. Without doubt, we must acknowledge that greenhouse and field trials are required to better understand this bacterium's potential role as a biocontrol vaccine for wheat when it is subjected to a competitive environment of an agricultural field with millions or billions of other soil microbes.

\section{MATERIALS AND METHODS}

\section{Strain and plasmids.}

The wheat cultivar (Triticum aestivum L) used was 'Sumai 188', which was purchased from Jiangsu Academy of Agricultural Sciences, Nanjing, China. B. velezensis CC09 was isolated from Cinnamomum camphora leaf tissues (Cai et al. 2013) and was stored at $-80^{\circ} \mathrm{C}$ in a freezer. Competent cells of Escherichia coli Trans 10 were purchased from TrashGen, Beijing. The shuttle plasmid PHT315-gfpmut $3 a$ was constructed by inserting a gene (gfpmut $3 a$ ) encoding GFP into plasmid PHT315, which can replicate in both $E$. coli and B. velezensis $\mathrm{CC} 09$.

\section{Stability of plasmid PHT315-gfpmut 3a \\ in B. velezensis CC09.}

The shuttle plasmid PHT315-gfpmut $3 a$ was used to transform competent cells of $B$. velezensis $\mathrm{CC} 09$, using the electroporation method, and the gfpmut $3 a$-transformed cells were screened on Luria Bertani (LB) plates containing antibiotic agent erythromycin at $10 \mu \mathrm{g} / \mathrm{ml}$. Positive transformants containing PHT315-gfpmut $3 a$ (i.e., GFP-tagged CC09) showed green fluorescence under microscopic observation (with a $488 \mathrm{~nm}$ excitation wavelength) and were cultured in antibioticfree liquid LB medium $(0.1 \%$, vol $/ \mathrm{vol})$ at $37^{\circ} \mathrm{C}, 160 \mathrm{rpm}$ for $65 \mathrm{~h}$, and were sampled every $5 \mathrm{~h}$. Each sample was plated on LB medium for colony counting. The percentage of colonies with green fluorescence compared with the total number of colonies reflected the plasmid stability in strain CC09.

\section{Effects of PHT315-gfpmut 3a on cell growth and antifungal activity.}

To test whether plasmid PHT315-gfpmut $3 a$ affects the biological properties of $B$. velezensis $\mathrm{CC} 09$, we did a comparative experiment measuring the growth curves of GFP-tagged CC09 and WT-CC09. Each strain was inoculated in LB medium $(0.1 \%, \mathrm{vol} / \mathrm{vol})$, cultured at $37^{\circ} \mathrm{C}, 160 \mathrm{rpm}$ for $60 \mathrm{~h}$, and was sampled every $5 \mathrm{~h}$, in order to measure the optical density at $600 \mathrm{~nm}$ by UV spectrophotometry (Huang et al. 2017).

To test the potential effect of PHT315-gfpmut $3 a$ on the antagonistic activity of strain CC09, two phytopathogenic fungi, G. graminis var. tritici and Bipolaris sorokiniana, were cultured separately on the center of PDA plates at $25^{\circ} \mathrm{C}$ for 5 and 7 days, respectively. GFP-tagged CC09 and WT-CC09 strains were then inoculated at about $3.0 \mathrm{~cm}$ apart from the mycelial edge of the test fungi and were investigated for growth inhibition against the G. graminis var. tritici and Bipolaris sorokiniana after 7 and 10 days, respectively, at $25^{\circ} \mathrm{C}$.

\section{Detection of strain colonization and migration in wheat plants in vivo.}

Healthy seeds of wheat cv. Sumai 188 were disinfected with $75 \%$ ethanol and $1 \%$ sodium hypochlorite, for 1 and $10 \mathrm{~min}$, respectively, followed by three washes with sterile water and

Table 2. Semiquantification $\left(2^{-\Delta \Delta C t}\right)$ of itu gene expression in root and leaf tissues ${ }^{\mathrm{a}}$

\begin{tabular}{|c|c|c|c|c|c|}
\hline Tissue & Treatment & $i t u A$ & $i t u B$ & $i t u C$ & $i t u D$ \\
\hline Roots & Strain CC09 & $\begin{array}{c}2.86 \pm 0.07 \\
-\end{array}$ & $\begin{array}{c}2.64 \pm 1.00 \\
-\end{array}$ & $\begin{array}{c}2.96 \pm 0.35 \\
-\end{array}$ & $\begin{array}{c}3.26 \pm 0.03 \\
-\end{array}$ \\
\hline Leaves & $\begin{array}{l}\text { Strain CC09 } \\
\text { Sterile water }\end{array}$ & $\begin{array}{c}0.86 \pm 0.04 \\
-\end{array}$ & $\begin{array}{c}0.98 \pm 0.04 \\
-\end{array}$ & $\begin{array}{c}1.00 \pm 0.16 \\
-\end{array}$ & $\begin{array}{c}0.95 \pm 0.11 \\
-\end{array}$ \\
\hline
\end{tabular}

\footnotetext{
a - indicates the expression of the genes was not detected.
}

Table 3. Design of the six treatments ${ }^{\mathrm{a}}$

\begin{tabular}{llll}
\hline No. & \multicolumn{1}{c}{ Treatments } & \multicolumn{1}{c}{ Roots $(\mathbf{A})^{\mathbf{b}}$} & \multicolumn{1}{c}{ Leaves (A) ${ }^{\mathbf{b}}$} \\
\hline 1 & Sterile water (control group) & Sterile water & Sterile water \\
2 & Strain CC09 (Bv) & GFP-tagged CC09 cells & Sterile water \\
3 & Pathogenic fungus (Bs) & Sterile water & Sterile water \\
4 & Fungicide-fungus (Tri-Bs) & Sterile water & Triadimefon \\
5 & Bacterium (in root)-fungus (Bv(r)-Bs) & GFP-tagged CC09 cells & Sterile water \\
6 & Bacterium (in leaves)-fungus (Bv(1)-Bs) & Sterile water & Bipolaris sorokiniana spores \\
\hline
\end{tabular}

${ }^{a}$ The same volume of sterile water, the green fluorescent protein (GFP)-tagged CC09 cells $\left(1 \times 10^{8} \mathrm{CFU} / \mathrm{ml}\right)$ and Bipolaris sorokiniana spores $\left(10^{6} \mathrm{CFU} / \mathrm{ml}\right)$ were inoculated on roots or leaves or both, according to described methods (Yang et al. 2014; Zhang and Yuen 1999).

${ }^{\mathrm{b}} \mathrm{A}$ is one day earlier than $\mathrm{B}$. 
were germinated in a sterilized tray in the dark at room temperature until the root length was 2 to $3 \mathrm{~cm}$. Fifteen germinated seeds were planted into a sterilized glass bottle $(9.5 \times 10.5 \mathrm{~cm})$ containing $30 \mathrm{~g}$ of sterilized perlite, were cultured in a light chamber at $25^{\circ} \mathrm{C}$, with a light period of 14-h days and 10 -h nights, until the two-leaf growth stage, and were inoculated with $30 \mathrm{ml}$ of the GFP-tagged CC09 suspension at $1 \times 10^{8}$ $\mathrm{CFU} / \mathrm{ml}$. The same amount of distilled water was used in a separate experiment as a negative control. Each treatment contained three replicates. Five days after inoculation, several root, stem, and leaf samples of wheat seedlings were collected at different timepoints. Some of the samples were sectioned by a bare-handed method and were observed with a laser scanning confocal microscope (Lei TCS SP8; Leica, Nussloch, Germany) for the distribution of the GFP-tagged CC09 in the wheat tissues or organs. The emission of GFP that was expressed in the GFP-tagged CC09 was measured by CLSM at 493 to $564 \mathrm{~nm}$, after excitation at $488 \mathrm{~nm}$, while plant spontaneous fluorescence was measured at 567 to $725 \mathrm{~nm}$, after excitation at $561 \mathrm{~nm}$ (Liu et al. 2006). The rest of the samples were weighed, were subjected to surface disinfection, and were ground up with a pestle and mortar, according to the method described by Dong et al. (2003). After removing the particles by instantaneous centrifugation, the homogenate was serially diluted in 10-fold increments and was cultured on solid LB medium with erythromycin $(10 \mu \mathrm{g} / \mathrm{ml})$, overnight at $37^{\circ} \mathrm{C}$, to determine the bacterial population per gram of tissue.

To test the effect of initial inoculation concentrations of the GFP-tagged CC09 on the growth of wheat seedlings, we performed an independent experiment the same as the one described above but with three inoculum densities $\left(1 \times 10^{6}, 1 \times 10^{7}\right.$ and $\left.1 \times 10^{8} \mathrm{CFU} / \mathrm{ml}\right)$. At 10 days postinoculation, the maximum size and mass of adventitious root as well as lateral root density and size on the maximum size of adventitious root for each seedling were counted and measured, respectively (Pierre-Jerome et al. 2016).

\section{Biocontrol effect of GFP-tagged CC09.}

Experimental design for wheat take-all disease. Disease control experiments were performed using a modification of a described method (Guilleroux and Osbourn 2004). In brief, experiments were conducted in 100-ml glass bottles containing a PDA dish ( $9 \mathrm{~cm}$ in diameter) either full of G. graminis var. tritici mycelium or with none, followed by the addition of $20 \mathrm{ml}$ of sterile moist perlite. Seven surface-sterilized seeds, either soaked in sterile water or the GFP-tagged CC09 suspension $\left(10^{8} \mathrm{CFU} / \mathrm{ml}\right)$ for $24 \mathrm{~h}$, were placed on top of the surface and were covered with $10 \mathrm{ml}$ of perlite, to form four treatments: i) $\mathrm{CK}$, a blank control without inoculation of G. graminis var. tritici and the GFP-tagged CC09; ii) $\mathrm{Bv}$, inoculation of the GFP-tagged CC09 only; iii) Ggt, inoculation of G. graminis var. tritici only; and iv) Bv-Ggt, inoculation of both G. graminis var. tritici and the GFP-tagged CC09. Each treatment had three replicates. Bottles were incubated in a light chamber at $25^{\circ} \mathrm{C}$, with a 14-h photoperiod. The disease incidence and biomass of the wheat were investigated 20 days after inoculation and were calculated using the formula described by Liu et al. (2009).

Experimental design for wheat spot blotch. Bipolaris sorokiniana was cultured on PDA medium at $25^{\circ} \mathrm{C}$ for 14 days. Spores of Bipolaris sorokiniana were washed with sterilized water and a suspension of $10^{6}$ cells $/ \mathrm{ml}$ was prepared. Wheat seedlings were cultured in glasses filled with perlite and were maintained in a light chamber at $25^{\circ} \mathrm{C}$, with a light period of 14-h days and 10-h nights, until the seedlings reached the twoleaf stage, before treatments were conducted. An overnight culture of the GFP-tagged CC09 was centrifuged to obtain the cells, which were washed three times with sterile water and were diluted to $1 \times 10^{8} \mathrm{CFU} / \mathrm{ml}$ (Yang et al. 2014; Zhang and Yuen 1999). All treatments were carried out within 2 days (Table 3). The incidence of wheat spot blotch was investigated at 10 days after treatment, following the method described by Knudsen et al. (1995).

\section{Determination of defensive enzyme activity.}

Root and leaf tissues were sampled separately or together at a certain time to determine the activity of PPO, POD, and PAL, based on described methods (Mollavali et al. 2016). Each treatment had three replicates and each sample was measured three times.

\section{Detection of expression of the iturin A synthetase-encoding genes in wheat tissues.}

The $\mathrm{p}_{\mathrm{itu}}$ promoter of the iturin A synthetase-encoding genes was fused to reporter gene gfpmut $3 a$ to form $\mathrm{p}_{\mathrm{itu}}-\mathrm{gfpmut} 3 a$, which was ligated into plasmid PHT315. The constructed plasmid was transmitted into $B$. velezensis $\mathrm{CC} 09$, resulting in an engineered strain, pH-IT-GFP_CC09. Ten days after inoculation of the strain on roots, several roots were sampled, were sectioned, and were observed using CLSM, to prove whether the GFP was expressed or not within root tissues (Chi et al. 2010).

Expression of itu genes of B. velezensis CC09 within wheat roots and leaves was evaluated using RT-PCR with three replicates. Total RNA was extracted from wheat roots and leaves in $\mathrm{CK}$ and $\mathrm{Bv}$ groups, respectively, using RNAprep pure plant kit (Tiangen, Beijing) according to the manufacturer's directions. First-strand complementary DNAs were synthesized in a $20-\mu \mathrm{l}$ final volume, using M-MuLV reverse transcription and random primer from PrimeScript first strand cDNA synthesis kit (Takara, Dalian, China). Relative semiquantitative RT-PCR was carried out on the StepOnePlus real-time PCR system (Applied Biosystems, Foster City, CA, U.S.A.), using a SYBR green detection protocol. The primers specific for ituA, ituB, ituC, and ituD as well as RNA polymerase $\beta$ subunit encoding gene $r p o B$ were described in Supplementary Table S1. Expression levels of the target genes were calculated with the $2^{-\Delta \Delta C t}$ method (Livak and Schmittgen 2001), using rpoB for normalization.

\section{Statistical analysis.}

Data were presented as the mean \pm standard deviation of three replicates. The one-way analysis of variance program was used for mean variance analysis by the Fisher's least significant difference test at $P<0.05$ with the GraphPad Prism software (version 3.02).

\section{ACKNOWLEDGMENTS}

We thank A. Javed for improving the quality of the writing.

\section{LITERATURE CITED}

Acharya, K., Dutta, A. K., and Pradhan, P. 2010. Bipolaris sorokiniana (Sacc.) Shoem.: The most destructive wheat fungal pathogen in the warmer areas. Aust. J. Crop Sci. 5:1064-1071.

Alvarez, F., Castro, M., Príncipe, A., Borioli, G., Fischer, S., Mori, G., and Jofré, E. 2012. The plant-associated Bacillus amyloliquefaciens strains MEP2 18 and ARP2 3 capable of producing the cyclic lipopeptides iturin or surfactin and fengycin are effective in biocontrol of sclerotinia stem rot disease. J. Appl. Microbiol. 112:159-174.

Arrebola, E., Jacobs, R., and Korsten, L. 2010. Iturin A is the principal inhibitor in the biocontrol activity of Bacillus amyloliquefaciens PPCB004 against postharvest fungal pathogens. J. Appl. Microbiol. 108:386-395.

Bithell, S. L., Mckay, A. C., Butler, R. C., and Cromey, M. G. 2016. Consecutive wheat sequences: Effects of contrasting growing seasons on concentrations of Gaeumannomyces graminis var. tritici DNA in soil and take-all disease across different cropping sequences. J. Agric. Sci. 154:472-486.

Borriss, R., Chen, X. H., Rueckert, C., Blom, J., Becker, A., Baumgarth, B., Fan, B., Pukall, R., Schumann, P., Spröer, C., Junge, H., Vater, J., Pühler, 
A., and Klenk, H. P. 2011. Relationship of Bacillus amyloliquefaciens clades associated with strains DSM $7^{\mathrm{T}}$ and FZB42 ${ }^{\mathrm{T}}$ : A proposal for Bacillus amyloliquefaciens subsp. amyloliquefaciens subsp. nov. and $\mathrm{Ba}$ cillus amyloliquefaciens subsp. plantarum subsp. nov. based on complete genome sequence comparisons. Int. J. Syst. Evol. Microbiol. 61: 1786-1801.

Cai, X. C., Kang, X. X., Xi, H., Liu, C. H., and Xue, Y. R. 2016. Complete genome sequence of the endophytic biocontrol strain Bacillus velezensis CC09. Genome Announc. 4: e01048-16.

Cai, X. C., Li, H., Xue, Y. R., and Liu, C. H. 2013. Study of endophytic Bacillus amyloliquefaciens $\mathrm{CC} 09$ and its antifungal cyclic lipopeptides. J. Appl. Biol. Biotechnol. 1:1-5.

Cai, X. C., Xi, H., Liang, L., Liu, J. D., Liu, C. H., Xue, Y. R., and Yu, X. Y. 2017. Rifampicin-resistance mutations in the rpoB gene in Bacillus velezensis $\mathrm{CC} 09$ have pleiotropic effects. Front. Microbiol. 8:178.

Chen, X. H., Koumoutsi, A., Scholz, R., Eisenreich, A., Schneider, K. Heinemeyer, I., Morgenstern, B., Voss, B., Hess, W. R., Reva, O., Junge, H., Voigt, B., Jungblut, P. R., Vater, J., Süssmuth, R., Liesegang, H., Strittmatter, A., Gottschalk, G., and Borriss, R. 2007. Comparative analysis of the complete genome sequence of the plant growth-promoting bacterium Bacillus amyloliquefaciens FZB42. Nat. Biotechnol. 25:1007-1014.

Chi, F., Yang, P., Han, F., Jing, Y., and Shen, S. 2010. Proteomic analysis of rice seedlings infected by Sinorhizobium meliloti 1021. Proteomics 10: 1861-1874.

Choudhary, D. K., and Johri, B. N. 2009. Interactions of Bacillus spp. and plants-With special reference to induced systemic resistance (ISR). Microbiol. Res. 164:493-513.

Chowdhury, S. P., Uhl, J., Grosch, R., Alquéres, S., Pittroff, S., Dietel, K., Schmitt-Kopplin, P., Borriss, R., and Hartmann, A. 2015. Cyclic lipopeptides of Bacillus amyloliquefaciens subsp. plantarum colonizing the lettuce rhizosphere enhance plant defense responses toward the bottom rot pathogen Rhizoctonia solani. Mol. Plant-Microbe Interact. 28:984-995.

Contesto, C., Milesi, S., Mantelin, S., Zancarini, A., Desbrosses, G., Varoquaux, F., Bellini, C., Kowalczyk, M., and Touraine, B. 2010. The auxin-signaling pathway is required for the lateral root response of Arabidopsis to the rhizobacterium Phyllobacterium brassicacearum. Planta 232:1455-1470.

Crane, J. M., Gibson, D. M., Vaughan, R. H., and Bergstrom, G. C. 2013. Iturin levels on wheat spikes linked to biological control of Fusarium head blight by Bacillus amyloliquefaciens. Phytopathology 103:146-155.

Dong, Y., Iniguez, A. L., and Triplett, E. W. 2003. Quantitative assessments of the host range and strain specificity of endophytic colonization by Klebsiella pneumoniae 342. Plant Soil 257:49-59.

Elwazziki, H., Elyousfi, B., and Serghat, S. 2015. Contributions of three upper leaves of wheat, either healthy or inoculated by Bipolaris sorokiniana, to yield and yield components. Aust. J. Crop Sci. 9:629-637.

Fernando, P. M., Marc, O., Laurent, F., Paulo, E. D. S., and Jorge, T. D. S. 2016. Effect of temperature, $\mathrm{pH}$ and substrate composition on production of lipopeptides by Bacillus amyloliquefaciens 629. Afr. J. Microbiol. Res. 10:1506-1512.

Gong, A. D., Li, H. P., Yuan, Q. S., Song, X. S., Yao, W., He, W. J., Zhang, J. B., and Liao, Y. C. 2015. Antagonistic mechanism of iturin A and plipastatin A from Bacillus amyloliquefaciens S76-3 from wheat spikes against Fusarium graminearum. PLoS One 10:e0116871.

Guilleroux, M., and Osbourn, A. 2004. Gene expression during infection of wheat roots by the take-all fungus Gaeumannomyces graminis. Mol. Plant Pathol. 5:203-216.

Haggag, W. M., and Timmusk, S. 2008. Colonization of peanut roots by biofilm-forming Paenibacillus polymyxa initiates biocontrol against crown rot disease. J. Appl. Microbiol. 104:961-969.

Hecker, M., and Völker, U. 1990. General stress proteins in Bacillus subtilis. FEMS Microbiol. Lett. 74:197-213.

Huang, M. H., Zhang, S. Q., Di, G. L., Xu, L. K., Zhao, T. X., Pan, H. Y., and Li, Y. G. 2017. Determination of a Bacillus velezensis strain for controlling soybean root rot. Biocontrol Sci. Techn. 27: 696-701.

Idriss, E. E., Makarewicz, O., Farouk, A., Rosner, K., Greiner, R., Bochow, H., Richter, T., and Borriss, R. 2002. Extracellular phytase activity of Bacillus amyloliquefaciens FZB45 contributes to its plant-growth-promoting effect. Microbiology 148:2097-2109.

James, E. K., Graham, P. H., and Vance, C. P. 2000. Nitrogen fixation in endophytic and associative symbiosis. Field Crops Res. 65:197-209.

Kim, P. I., Ryu, J., Kim, Y. H., and Chi, Y. T. 2010. Production of biosurfactant lipopeptides Iturin A, fengycin and surfactin A from Bacillus subtilis CMB32 for control of Colletotrichum gloeosporioides. J. Microbiol. Biotechn. 20:138-145.

Knudsen, I. M. B., Hockenhull, J., and Jensen, D. F. 1995. Biocontrol of seedling diseases of barley and wheat caused by Fusarium culmorum and
Bipolaris sorokiniana: Effects of selected fungal antagonists on growth and yield components. Plant Pathol. 44:467-477.

Liu, B., Qiao, H., Huang, L., Heinrich, B., Han, Q., Kang, Z., and Gong, Y 2009. Biological control of take-all in wheat by endophytic Bacillus subtilis E1R-j and potential mode of action. Biol. Control 49:277-285.

Liu, G., Kong, Y., Fan, Y., Geng, C., Peng, D., and Sun, M. 2017. Wholegenome sequencing of Bacillus velezensis LS69, a strain with a broad inhibitory spectrum against pathogenic bacteria. J. Biotechnol. 249: 20-24.

Liu, J. L., Xue, Y. R., and Liu, C. H. 2014. Optimization of shake flaskfermentation conditions for iturin a production by endophytic Bacillus amyloliquefaciens CC09. Microbiol. China. 41:75-82.

Liu, X., Zhao, H., and Chen, S. 2006. Colonization of maize and rice plants by strain Bacillus megaterium C4. Curr. Microbiol. 52:186-190.

Livak, K. J., and Schmittgen, T. D. 2001. Analysis of relative gene expression data using real-time quantitative PCR and the $2^{-\Delta \Delta C(T)}$ method. Methods 25:402-408.

Mangmang, J. S., Deaker, R., and Rogers, G. 2015. Optimal plant growthpromoting concentration of Azospirillum brasilense inoculated to cucumber, lettuce and tomato seeds varies between bacterial strains. Israel J. Plant Sci. 62:145-152.

McDonald, M. C., Ahren, D., Simpfendorfer, S., Milgate, A., and Solomon, P. S. 2018. The discovery of the virulence gene ToxA in the wheat and barley pathogen Bipolaris sorokiniana. Mol. Plant Pathol. 19:432-439.

Merritt, P. M., Danhorn, T., and Fuqua, C. 2007. Motility and chemotaxis in Agrobacterium tumefaciens surface attachment and biofilm formation. J. Bacteriol. 189:8005-8014.

Mollavali, M., Bolandnazar, S. A., Schwarz, D., Rohn, S., Riehle, P., and Zaare Nahandi, F. 2016. Flavonol glucoside and antioxidant enzyme biosynthesis affected by mycorrhizal fungi in various cultivars of onion (Allium cepa L.). J. Agric. Food Chem. 64:71-77.

Pandya, U., and Saraf, M. 2014. In vitro evaluation of PGPR strains for their biocontrol potential against fungal pathogens. Pages 293-305 in: Microbial Diversity and Biotechnology in Food Security. R. Kharwar, R. Upadhyay, N. Dubey, and R. Raghuwanshi, eds. Springer, New Delhi

Pereg, L., and McMillan, M. 2015. Scoping the potential uses of beneficial microorganisms for increasing productivity in cotton cropping systems. Soil Biol. Biochem. 80:349-358.

Pierre-Jerome, E., Moss, B. L., Lanctot, A., Hageman, A., and Nemhauser, J. L. 2016. Functional analysis of molecular interactions in synthetic auxin response circuits. Proc. Natl. Acad. Sci. U.S.A. 113:11354-11359.

Savary, S., Djurle, A., Yuen, J., Ficke, A., Rossi, V., Esker, P., Fernandes, J. M., Del, P. E., Kumar, J., and Madden, L. V. 2017. A white paper on global wheat health based on scenario development and analysis. Phytopathology 107:1109-1122.

Shali, A., Ghasemi, S., Ahmadian, G., Ranjbar, G., Dehestani, A., Khalesi, N., Motallebi, E., and Vahed, M. 2010. Bacillus pumilus SG2 chitinases induced and regulated by chitin, show inhibitory activity against Fusarium graminearum and Bipolaris sorokiniana. Phytoparasitica 38: 141-147.

Spaepen, S., Bossuyt, S., Engelen, K., Marchal, K., and Vanderleyden, J. 2014. Phenotypical and molecular responses of Arabidopsis thaliana roots as a result of inoculation with the auxin-producing bacterium Azospirillum brasilense. New Phytol. 201:850-861.

Vacheron, J., Desbrosses, G., Bouffaud, M. L., Touraine, B., MoënneLoccoz, Y., Muller, D., Legendre, L., Wisniewski-Dyé, F., and PrigentCombaret, C. 2013. Plant growth-promoting rhizobacteria and root system functioning. Front. Plant Sci. 4:356.

Verbon, E. H., and Liberman, L. M. 2016. Beneficial microbes affect endogenous mechanisms controlling root development. Trends Plant Sci. 21:218-229.

Winter, M., Mol, F. D., and Tiedemann, A. V. 2014. Cropping systems with maize and oilseed rape for energy production may reduce the risk of stem base diseases in wheat. Field Crops Res. 156:249-257.

Yang, H., Xue, Y., Xiangyang, Y. U., and Liu, C. 2014. Colonization of Bacillus amyloliquefaciens $\mathrm{CC} 09$ in wheat leaf and its biocontrol effect on powdery mildew disease. Chin. J. Biol Control 30:481-488 (in Chinese).

Zhang, N., Wang, D., Liu, Y., Li, S., Shen, Q., and Zhang, R. 2014. Effects of different plant root exudates and their organic acid components on chemotaxis, biofilm formation and colonization by beneficial rhizosphereassociated bacterial strains. Plant Soil 374:689-700.

Zhang, Y., Wang, G., Wang, Y. F., and Liu, F. Y. 2006. Control efficacy and inhibitory action of Bacillus subtilis B_(2-47) strain on wheat take-all and its pathogenic fungi. J. Henan Univ. 1:19 (in Chinese).

Zhang, Z., and Yuen, G. Y. 1999. Biological control of Bipolaris sorokiniana on tall fescue by Stenotrophomonas maltophilia strain C3. Phytopathology 89:817-822. 